\title{
Causes of Delay for Construction Projects
}

\author{
Shankar $\mathrm{C}^{1}$,Saranya $\mathrm{K}^{2}$, Col Jacob G Podipara ${ }^{3}$,V S Srinithee ${ }^{4}$ \\ 1, Assistant Professor, Department of Civil Engineering ,Coimbatore Institute of Technology, Coimbatore -14 \\ ${ }^{2}$ Assistant Professor, Department of Civil Engineering, Sri Ramakrishna Engineering College, Coimbatore-22 \\ 3, Associate Professor, Department of Civil Engineering, Coimbatore Institute of Technology, Coimbatore-14 \\ ${ }^{4,}$ Student , Department of Civil Engineering , Coimbatore Institute of Technology, Coimbatore-14 \\ ${ }^{1}$ shankar.c@cit.edu.in ${ }^{2}$ saranyakcivil8@gmail.com , ${ }^{3}$ jacobpodipara@cit.edu.in, ${ }^{4}$ nithi.sri29@gmail.com
}

\begin{abstract}
Delay can be delay can be defined as the extra time required or incurred either beyond the stipulated completion date or beyond the date that the project stakeholders agreed upon for the completion of the project. The various effects of delay include time overrun, cost overrun, dispute, Total abandonment, Litigation, Arbitration. The objective this study is to review various journals on causes of delay for construction projects. Hence in this paper a number journals are summarized and suggestion for reducing delay in construction is given.

Keywords:

Construction delay, Causes of delay, Effects of delay, Time and Cost Overrun.
\end{abstract}

\section{Introduction}

Construction without delay has completely reduced in today's construction industry. There are various types of delay including Critical or Non-Critical Delays, Excusable or Non-Excusable Delays, Compensable or Non-Compensable Delays, Concurrent or Non-Concurrent Delays. The delay can be Project related delay, Owner related delay, Contractors related delays, Consultant related delays, Design related delay, Material related delays, Equipment related delays, Labour related delays, External factors related delays. It is evident that delay generally has a major impact on both cost and duration of the project. However these delay can be minimized by effective management of various projects.

\section{Literature Review}

In the study of Aditi Dinakar, Delay is defined as late completion of project as compared to planned schedule. This study focuses on various causes of delay, its impact on the construction and the various methods on how to minimize the delays in the construction site. This has considered the Construction of New District Jail in Kurnool District of Andhra Pradesh. Day to day data were collected from site including Starting time, Finishing time and duration, Gantt Chart was generated using MS Project and critical activities were analysed. A questionnaire consisting of 7 sections containing 9 questions each based on observations of site was prepared and the views on the same from various parties involved in a project. MINITAB software was used for analysis. It was observed that delay in the project was mostly from contractor's side and other reasons include improper communication between various parties, lack of qualified labor, equipment and material [1]. 
The study of Ghanim A. Bekr has identified the most significant delay causes in large-scale public projects and the effect of these delays on the achievements of these types of projects. A questionnaire with three divisions was made first containing the details of the respondent second includes the causes and were categorized into four groups. The significant factors within each group were selected as those with Importance Index (I.I) higher than the mean I.I. of the group and this study also revealed the considerable effects of delay. Inadequate management and supervision by the contractor, Clients changes of the design, Cash flow problems suffered by the contractor's comes in the third most significant cause of delay for the large scale public construction projects in Jordan were three main causes of delay [2].

The study of Jeffrey Boon Hui Yap et al involves a field survey that acquires the views of 148 Malaysian construction practitioners from client, consultant and contractor organizations. This study identifies the causes of delay that was categorized under Client, Contractor, Labour and Equipment, Material and Other related. This main causes were identified by conducting field survey and important indices was determined by considering both frequency and severity indices. And this study also evaluates the factors affecting schedule performance. The factor analysis has identified the five principal factors involved to be competency management, communication and coordination management, financial management, risk management and site management [3].

Syed Mohammad Tahir Naqash et al explores significant factors causing delay in Northern Region of India. Relative Important Index method was used to find out the most significant factors causing delays. The result obtained from the survey revealed that the major causes for delays are; delays in payments, design errors, poor site management, lack of expertise in project management, contract duration, change in material prices, corruption, and poor estimation. The top 10 factors were correlated with cost of the project [4].

The objective of the Manoj Sharma's Causes of Delays in Indian Construction Industries was to identify the source of delays for construction projects, to study cost of delay and methods to mitigate delays, to study the effect of delays for construction projects, to analysis of data collected of live projects regarding delays of activity and to give suggestion for minimum of effects of delays for construction projects. The factors causing delay were identified from past literatures.And the top 10 delay factors related to Consultant, Contractors, Material, Plant and Equipment and other external factors was determined by doing analysis using Relative Imporatant Index (RII) [5].

Subhav Singh et al, identifies the various attributes for construction project delay, using the residential building projects as a starting point. Feedback from a survey conducted to the contractors and consultants and was analysed using Relative Importance Index (RII). The results have shown that shortage of materials on site; unforeseen ground conditions; poor procurement planning; problems to access the site; rework; weather conditions; inadequate modern equipment; skilled workforce; and equipment failure are ranked by the contractors and consultants as the main causes of project delays in India [6].

Akshaykumar $\mathrm{C}$ has reviewed effectively the causes of delays.The causes of delays was identified through literature reviews in Indian construction projects. The methodology adopted was literature review. As result of this study the causes of Excusable compensable delays, Non excusable delays, Triggering delays were obtained [7]. 
Ghada Taha has developed a model to evaluate the causes of delay. The objective of this study was to identify the main causes of delay in construction projects from the point of view of contractor and consultant and to develop a model to evaluate the top five causes of delay in construction projects. a literature search and interviews was carried out. As a result of literature review and interview 63 causes of delay were grouped into 10 groups as: Project related, Owner related, Consultant related, Contractor related, subcontractor related, Labour related, contract related, Material related, Equipment related, and External factors depending on their nature and mode of occurrence. The factors that causes on delay of the construction project is Delay in progress payments owner, Poor site management and supervision by contractor, Lack in qualified labours, Difficulties in financing project by contractor, ineffective planning and scheduling of project by contractor. The model was designed using Virtual Basic.net in order evaluate the top five factor and hence to reduce project delay [8].

Waqar Ahmad Paray in Delay Analysis in Construction Project has determine the causes of delay, to determine the results caused by delay, to review the utilization of advanced tools and techniques in managing delays. The major causes identified include Strikes, external or internal military actions, Unforeseen condition/natural calamities, Mistakes in soil investigation, Slow permits by government agencies, Unfavorable web site conditions. The causes were identified through questionnaire survey and by computing RII the causes were ranked accordingly [9].

The objective of N. Hamzaha et al is to construct a theoretical framework that causes construction delay in public higher education institution in Malaysia. The causes of delay are collected from the previous international journal paper. The literature reviews were summarized and the delay framework was constructed based upon the literature review summary for a public higher learning institution. The consequence of this study is to make a future study about the cause of delays for projects in the Ministry of Higher Education Malaysia [10].

The aim of the study by Dinesh Kumar is to find out the most significant factors causing delays in Indian construction projects through literature review and questionnaire survey. From the literature review 103 causes of delays categorized into 8 different groups, 8 effects of delays were found. Further, the Questionnaire survey is conducted with the participants (contractors, owners, consultants and others) of Indian construction industry in order to shortlist the top 20 significant factors with respect to Indian context were obtained and finally recommendations are given to avoid delays in construction project. RII was determined to obtain the top causes. As result it was identified that Inadequate contractor's work \& experience \& their poor risk management and ignorance is first important cause of delay and communication and coordination between the participants as second most important cause though both the top two causes same value of RII [11].

Surabattuni Murali has identified and prioritized the major causes of time and cost overrun in construction industry using a completed project. Data is collected from Shan-E-Awadh-ground anchoring project, Lucknow, the data is analyzed and compared with the estimated and actual budget schedules to understand the causes of cost and time overruns. Factors causing time and cost overrun were identified from the project using questionnaire with the help of workers, who 
worked for the project as consultants, contractors, site engineers, etc. The results of the study has shown that main factors of the time and cost overruns are poor material management, site conditions, unskilled labours, contractor financial difficulties, machines and equipment difficulties [13].

\section{Conclusion}

Delay in the construction projects can be minimized by hiring qualified and experienced staff for site management and supervision, by improving communication and co-ordination between various people involved in the construction project, by conducting frequent progress meeting, by effective strategic planning, by proper material procurement, by preparing accurate initial cost estimates

\section{References}

1. Aditi Dinakar, "Delay Analysis in Construction Project", 2014, International Journal of Emerging Technology and Advanced Engineering

2. Jordan, Ghanim A. Bekr, "Study And Assessment of Causes And Effects Of Delay In Large Public Construction Projects In Jordan", 2018, International Journal of Applied Engineering Research

3. Jeffrey Boon Hui Yap, Pei Ling Goay, Yoke Bee Woon, Martin Skitmore, "Revisiting Critical Delay Factors For Construction Analysis Projects in Malaysia", 2020, Alexandria Engineering Journal.

4. Syed Mohammad Tahir Naqash, Sandeep Singla, "Significant factors affecting delay in Construction Projects in Northern Region of India And their Relation with Cost", 2020 International Journal of Scientific \& Technology Research Manoj Sharma, Dr. A. S. Trived, Yash Upadhaya,

"Causes of Delays in Indian Construction Industries", 2017, International Journal for Research in Applied Science \& Engineering Technology (IJRASET)

5. Subhav Singh, Anju Bala, Saurav Dixit, Deekshant Varshney, "Critical Analysis of Causes Of Delay in Residential Construction Projects in India”, 2018, International Journal of Civil Engineering and Technology (IJCIET)

6. Akshaykumar C. Pandya, Dr. Shakil S. Malek, "A Review for the causes of delay in Indian Construction Projects"2018, International Journal of Advance Engineering and Research Development

7. Ghada Taha, Mohamed Badawy, Omar El-Nawawy, "A Model for Evaluation of Delays in Construction Projects", 2016, International Journal of Innovative Research in Science, Engineering and Technology

8. Waqar Ahmad Paray, Chitranjan Kumar, "Delay Analysis in Construction Project", 2014, International Research Journal of Engineering and Technology (IRJET) 
9. N. Hamzaha, M.A. Khoirya, I. Arshada, N. M. Tawilb and A. I. Che Anib, "Cause of Construction Delay - Theoretical Framework", 2011, The 2nd International Building Control Conference, Elsevier

10. Dinesh Kumar R, “Causes and Effects of Delays in Indian Construction Projects”, 2016, International Research Journal of Engineering and Technology (IRJET)

11. Prakash Rao, B. and Joseph Camron Culas "Causes of Delay in Construction Projects - A Case Study", 2014, International Journal of Current Research

12. Surabattuni Murali, Sanjeet KumaR, “Factors Affecting Overruns Construction Time and Cost: A Case Study”, 2019, International Journal of Recent Technology and Engineering (IJRTE)

13. Akshay M. Tayade and Parag S. Mahatme, "Delay in Construction its Causes and Mitigation: A review", 2019, International Research Journal of Engineering and Technology (IRJET)

14. Ayman H. Al-Momani ," Construction Delay : A Quantitative Analysis" , 2000, International Journal of Project Management

15. Shabbab Al Hammadi, M.Sadique Nawab , "Study of Delay Factors in Construction Projects", 2016, International Advanced Research Journal in Science, Engineering and Technology

16. Mukilan K, Rameshbabu C," Influencing Risk Factors in Construction Projects based on Time and Cost Overrun", 2019, International Journal of Recent Technology and Engineering (IJRTE) 